Rapp. Grønlands geol. Unders. 99, 73-78 (1980)

\title{
NOTES ON THE LOWER PALAEOZOIC CLASTIC SEDIMENTS OF PEARY LAND, NORTH GREENLAND
}

\section{John M. Hurst and Finn Surlyk}

Clastic sediments of Precambrian(?) to Silurian age outcrop over large areas of Peary Land (fig. 35). Total sediment thickness approaches 3 to $4 \mathrm{~km}$, of which Silurian clastics account for approximately half. The main outcrop of Silurian clastics is south of Frederick E. Hyde Fjord whilst pre-Silurian clastic sediments mainly outcrop to the north of the fjord (fig. 35).

Previous descriptions of the sediments north of Frederick E. Hyde Fjord - O. B. Bøggild Fjord (A. fig. 35) have been given by Fränkl (1955), Dawes (1971, 1976) and Dawes \& Soper $(1973,1979)$; sediments to the south of the fjords have only been briefly described (Christie \& Peel, 1977; Hurst, 1979). Since the work of Fränkl (1955) and more recently Dawes \& Soper (1973) it is apparent that correlation of sediments across the Harder Fjord fault (fig. 36) is complicated.

The primary aim of the 1979 field season was to evaluate the stratigraphy of the trough

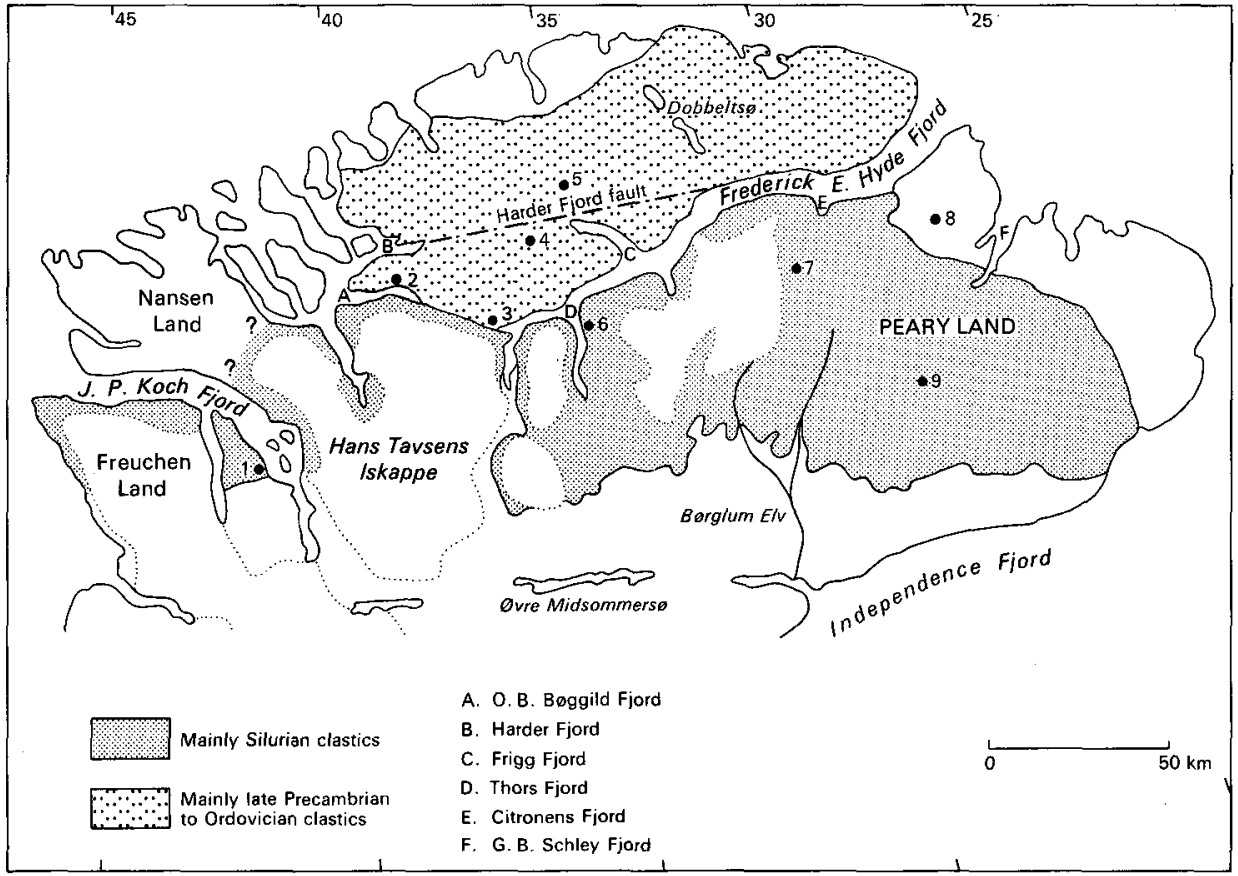

Fig. 35. Locality map showing simplified distribution of trough clastic sediments, in Peary Land and environs. Numbers refer to localities mentioned in the text. 
clastic sediments and gain an understanding of the sedimentary processes and environments involved in their formation. Special attention was paid to correlation across the Harder Fjord fault because Dawes (1976) suggested that the youngest folded sediments to the north of the fault were mainly of Silurian age and, possibly extended into the Devonian.

\title{
General stratigraphy
}

\author{
South of Harder Fjord fault
}

\section{Pre-Ordovician sediments}

South of the Harder Fjord fault (fig. 35) and north of the O. B. Bøggild Fjord - Frederick E. Hyde Fjord axis, the oldest sediments are the Frigg Fjord mudstones of Fränkl (1955) (see also Dawes \& Soper, 1973). This unit, which mainly occurs in the environs of the Harder Fjord fault zone, consists of variegated purple and green mudstones and distal turbidites, at least $100 \mathrm{~m}$ thick.

At locality 4 (fig. 35) the Frigg Fjord mudstones pass conformably up into a thick sequence $(c .1000 \mathrm{~m})$ of turbidites, mudstones, black and green cherts. Dawes \& Soper (1979) referred to the upper part of this sequence in $\mathrm{O}$. B. Bøggild Fjord (locality 2 on fig. 35) as formation A (fig. 36). The turbidites were deposited in the outer parts of deep-sea fan systems fed from the shelf regions to the south. Several distinctive beds of redeposited chert and carbonate conglomerate occur in the upper part of the sequence. These sediments were probably transported by high density debris flows from the edge of the carbonate shelf, and are traceable from O. B. Bøggild Fjord to Frigg Fjord (C. fig. 35).

A Cambrian age is probable for both the Frigg Fjord mudstones and the overlying sequence including formation $\mathrm{A}$, as they occur immediately below lowest Ordovician graptolite faunas. Other fossils are rare, consisting mainly of sponge spicules. A rich, but apparently not very diverse, trace fossil fauna occurs in parts of the Frigg Fjord mudstone.

\section{Ordovician sediments}

The Ordovician sediments north of O. B. Bøggild Fjord - Frederick E. Hyde Fjord, conformably follow the Cambrian succession. These consist of a thick sequence of mudstones, black cherts and chertified mudstones, with Lower Ordovician graptolites, and are very similar to the Hazen Formation of Ellesmere Island, Canada. In the Hare Bugt (locality 3 fig. 35 ) to Frigg Fjord area the sequence contains thick chert and carbonate clast conglomerates. The conglomerates are composed of predominantly slope derived clasts but their areal restriction may indicate localized tectonic activity. The conglomerates thin drastically along strike towards $\mathrm{O}$. B. Bøggild Fjord and northwards to the Harder Fjord fault.

The remaining Ordovician sediments consist of cherts, mudstones, distal turbidites and very thin chert and carbonate conglomerates. Dawes \& Soper (1979) referred to the whole Ordovician sequence in O. B. Bøggild Fjord (locality 2 on fig. 35) as formation B (fig. 36). 


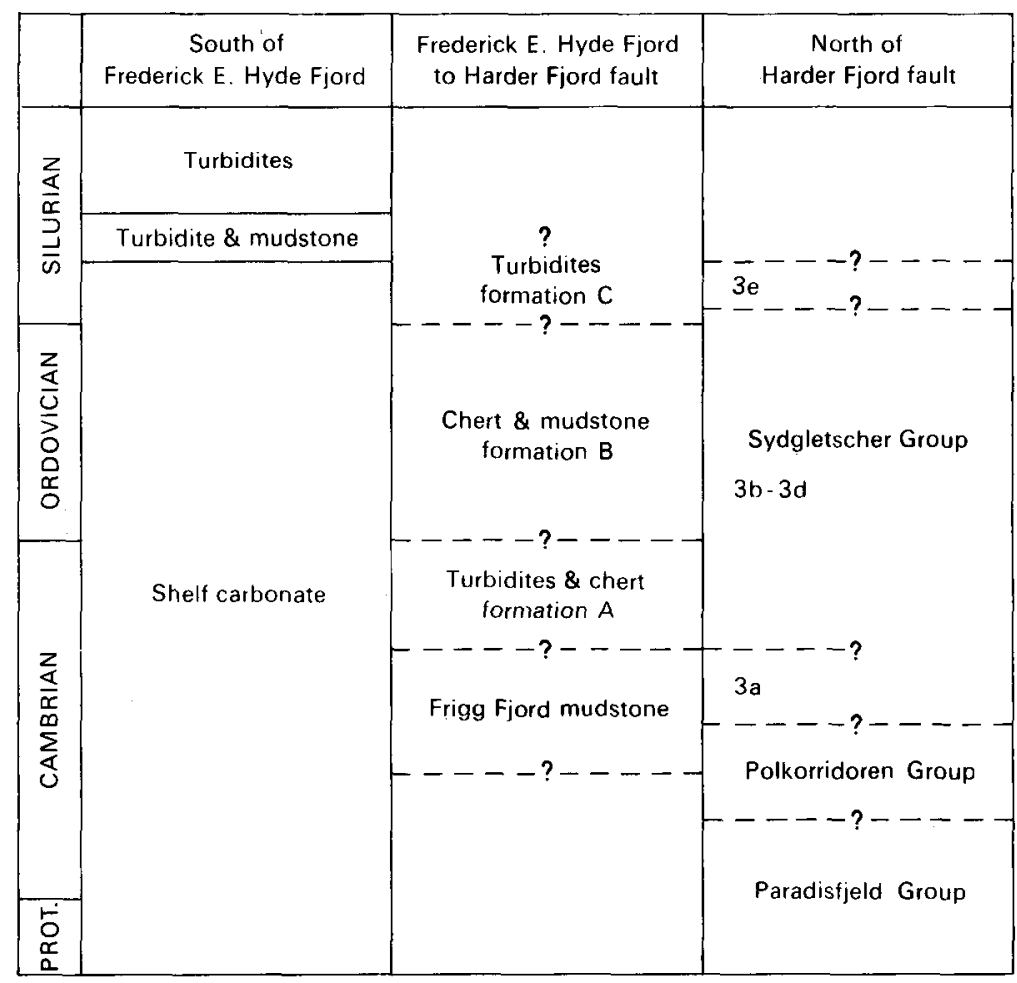

Fig. 36. Very simplified stratigraphy of the trough clastic sediments of Peary Land and environs (partly after Dawes \& Soper, 1973, 1979).

\section{Silurian sediments}

The main outcrop of Silurian sediments is to the south of Frederick E. Hyde Fjord, in which Christie \& Peel (1977) recognised a Silurian shale and a Silurian flysch formation. North of the fjord, but south of the Harder Fjord fault, only isolated outcrops of Silurian sediments occur. At O. B. Bøggild Fjord (locality 2 on fig. 35) Dawes \& Soper (1979) referred to the Silurian sediments as formation $\mathrm{C}$ (fig. 36).

Silurian sediments consist mainly of fine grained sand turbidites of outer fan to basin plain origin. The main direction of transport appears to have been along strike to the west-southwest. In the lower part of the succession there are three horizons of redeposited carbonate conglomerate containing both Ordovician and Silurian faunas. One, two, or three of these occur in different sections along the south coast of Frederick E. Hyde Fjord, between Thors Fjord (D fig. 35) and Citronens Fjord (E fig. 35). The conglomerates were probably derived from the southerly shelf edge which trended sub-parallel to Frederick E. Hyde Fjord.

During the uppermost Llandovery (Silurian), the northern part of the carbonate platform collapsed and became part of the trough whereby the shelf carbonates became overlain by a thick turbidite sequence (fig. 36; Christie \& Peel, 1977). Initially the clastics consisted of a sequence of muds and fine-grained sand and silt turbidites which grade into muds in south Peary Land. The whole sequence, which Christie \& Peel (1977) referred to as the un-named 
Silurian black shale formation, is approximately $100 \mathrm{~m}$ thick and occurs in the middle of the total Silurian clastic succession.

Subsequently, a thick sequence of generally fine-grained sand turbidites were deposited, with some fine chert pebble conglomerates and several major fining upward units (locality 7 on fig. 35), followed by a resedimented chert conglomerate unit in east Peary Land (locality 9 on fig. 35 ). The conglomerate forms the youngest part of the Lower Palaeozoic (Wenlock ?) sequence in Peary Land. In the upper turbidites, transport direction is still mainly to the west-southwest.

\section{North of Harder Fjord fault}

North of this lineament Dawes \& Soper (1973) erected a tri-partite stratigraphy, based on the earlier work of Fränkl (fig. 36). Prior to this field season, no age-diagnostic fossils had been found from these sequences, so correlation with strata to the south of the Harder Fjord fault was on a lithostratigraphic basis only. Consequently, Dawes (1976) tentatively correlated the upper turbiditic part of the Polkorridoren Group with Silurian turbidites to the south, and suggested that the overlying Sydgletscher Group may extend into the Devonian. A new lithostratigraphic correlation is proposed here, which is strongly substantiated by the first find of age-diagnostic fossils north of the Harder Fjord fault.

\section{Paradisfjeld Group}

Some of the oldest sediments north of the Harder Fjord fault are turbidites, lime mudstones and carbonate conglomerates of the Paradisfjeld Group. Fossils indicate that the highest part is of Cambrian or younger age (J. S. Peel, personal communication, 1979), but the younger age possibility is excluded on regional grounds. The group may extend down into the Proterozoic, and in places is underlain by quartzites (Soper et al., this report).

\section{Polkorridoren Group}

The overlying Polkorridoren Group comprises thick-bedded, fine, medium and coarse-grained sand turbidites in thick packets, alternating with thin-bedded turbidites and mudstones, generally purple and green in colour. The thicker bedded, coarser grained turbidite wedges are not known south of the Harder Fjord fault, whereas the more variegated purple and green sediments are possibly represented by the Frigg Fjord mudstone in and around the Harder Fjord fault zone. It is thus considered more appropriate to include the Frigg Fjord mudstone in the Polkorridoren Group, rather than placing it as the basal unit of the Sydgletscher Group as done by Dawes \& Soper (1973). Possibly the Frigg Fjord mudstone can be interpreted as representing the slope facies, as well as basinal background sediment, of the turbidite wedges of the Polkorridoren Group. Transport direction of the turbidites is towards both north and west, and very occasionally east.

No body fauna is known from the Polkorridoren Group, but the purple and green units occasionally display intense burrowing. Owing to new evidence on the age of the overlying Sydgletscher Group, it is unlikely that the Polkorridoren Group is younger than Ordovician. It is probably of Cambrian age. A correlation with other Cambrian sediments is perhaps strengthened by the fact that in northeast Peary Land (locality 8 on fig. 35), in and around 
the eastern extension of the Harder Fjord fault, the Lower Cambrian Buen Formation (equivalent to Schley Fjord shale of Troelsen, 1956) is characteristically composed of greygreen mudstones (Christie \& Ineson, 1979).

\section{Sydgletscher Group}

A poorly preserved graptolite assemblage from the upper part of unit 3d (Dawes \& Soper, 1973), upper Sydgletscher shales (locality 5 on fig. 35), indicates an early Llandovery (Silurian) age (M. Bjerreskov, personal communication, 1979). This suggests that the $3 \mathrm{~b}$ to 3d part of the Sydgletscher Group (fig. 36) is equivalent to the Ordovician and Cambrian sediments (formations A and B) to the south of the Harder Fjord fault; this suggestion is strengthened by the strong lithological resemblance. The Sydgletscher quartzite (unit 3c) is identical with the cherts, and the shale units are a mixture of mudstone, distal turbidite and fine pebble conglomerates. Further, the uppermost Sydgletscher sandstone (3e; fig. 36) is comparable with the fine-grained Silurian turbidites $(\mathrm{fm}$. C) found to the south.

\section{General conclusion of fieldwork}

(1) The evolution of the east-west trending North Greenland trough was initiated in late Proterozoic or Cambrian time and continued throughout Ordovician and into Silurian times.

(2) The trough was formed by rifting and the southern margin was controlled by major, en echelon, east-west trending fault systems. The northern margin is not known as it is probably situated under the present Arctic Ocean.

(3) The trough expanded, in several episodes, by southwards shift of the southern margin to new fault systems. During this process the older fault system became intrabasinal and largely inactive.

(4) The first phase of trough fill mainly comprises dark mudstones, light lime mudstone and resedimented conglomerates, reflecting the incipient nature of the rift.

(5) Subsequently, in Cambrian times a phase of turbidite sedimentation reflects deeper water, and a greater differentiation of shelf and trough. Transport direction was both lateral from south and north, and longitudinal from the east. At the end of this phase, turbidite sedimentation was punctuated by several episodes of conglomeratic gravity flows initiated on the platform margin and upper slope.

(6) In the latest Cambrian the supply of coarser clastics dramatically decreased, and the Ordovician was characterized by slow deposition of black mudstones and cherts, probably in a deeply submerged narrow rift. Thick, resedimented conglomerates derived from the margin of the carbonate platform and the upper slope were deposited along the southern margins of the trough.

(7) The transition from Ordovician to Silurian was marked by a new phase of turbidite sedimentation and a sequence several kilometres thick was deposited in the trough during the Lower and Middle Silurian. The Silurian turbidites from eastern Peary Land to Freuchen Land (fig. 35) were transported from the east along the trough. Only very few palaeo-current measurements indicate movement of sediment across the trough or from west to east. Consequently, at present there is no direct evidence for a northern source area ('Pearya', see Trettin, 1971) during deposition of the main North Greenland turbidite sequence. However, the strongly unidirectional transport along strike indirectly suggests the existence of a north- 
ern barrier, which together with the southern platform-slope system, created a westward plunging trough.

(8) The trough margin during the first phase of Silurian turbidite sedimentation was controlled by a major east-west fault zone running through J. P. Koch Fjord and about 20 $\mathrm{km}$ south of Frederick E. Hyde Fjord. During the Llandovery-Wenlock transition the platform margin collapsed and all of Peary Land became part of the trough. The position of the new border fault is not known, but the onlapping turbidite sequence can be followed several hundred kilometres to the south, at least as far as the east coast of Valdemar Glückstadt Land and the west coast of northern Kronprins Christian Land (J. S. Peel, personal communication, 1979).

(9) Silurian turbidite sedimentation was periodically interrupted by deposition of resedimented conglomerates derived from the upper slope and platform margin. The youngest preserved deposits of the North Greenland trough in Peary Land represent a major phase of chert conglomerate deposition.

(10) The Ordovician formation B of Dawes \& Soper (1979) is lithostratigraphically correlated with parts of $3 \mathrm{~b}$ to $3 \mathrm{~d}$ of the Sydgletscher Group of the fold belt. This contrasts strongly with earlier correlation between rocks north and south of the Harder Fjord fault by Dawes (1976) and Dawes \& Soper (1979), who tentatively correlated the Sydgletscher Group with the higher parts of formation $C$ of late Silurian and possibly Devonian age.

(11) The revised lithostratigraphic correlation was substantiated by our find, in the top of $3 \mathrm{~d}$ of the Sydgletscher Group, of the first age-diagnostic fossils north of the Harder Fjord fault. The fossil assemblage comprises graptolites of earliest Llandovery age (det. Merete Bjerreskov), implying an Ordovician or older age for the bulk of the group.

(12) Finally, a detailed lithostratigraphic scheme has been formulated for the whole Lower Palaeozoic trough sequence throughout North Greenland (Hurst \& Surlyk, unpublished).

\section{References}

Christie, R. L. \& Ineson, J. R. 1979: Precambrian - Silurian geology of the G. B. Schley Fjord region, eastern Peary Land, North Greenland. Rapp. Grønlands geol. Unders. 88, 63-71.

Christie, R. L. \& Peel, J. S. 1977: Cambrian - Silurian stratigraphy of Børglum Elv, Peary Land, eastern North Greenland. Rapp. Grønlands geol. Unders. 82, 48 pp.

Dawes, P. R. 1971: The North Greenland fold belt and environs. Bull. geol. Soc. Denmark 20, 197-239.

Dawes, P. R. 1976: Precambrian to Tertiary of northern Greenland. In Escher, A. \& Watt, W. S. (edit.) Geology of Greenland, 248-303. Copenhagen: Geol. Surv. Greenland.

Dawes, P. R. \& Soper, N. J. 1973: Pre-Quaternary history of North Greenland. In Pitcher, M. G. (edit.) Arctic Geology. Mem. Am Ass. Petrol. Geol. 19, 117-134.

Dawes, P. R. \& Soper, N. J. 1979: Structural and Stratigraphic framework of the North Greenland fold belt in Johannes V. Jensen Land, Peary Land. Rapp. Grønlands geol. Unders 93, 40 pp.

Fränkl, E. 1955: Rapport über die Durchquerung von Nord Peary Land (Nordgrönland) im Sommer 1953. Meddr Grønland 103(8), $61 \mathrm{pp}$.

Hurst, J. M. 1979: Uppermost Ordovician and Silurian geology of north-west Peary Land, North Greenland. Rapp. Grønlands geol. Under. 88, 41-49.

Trettin, H. P. 1971: Geology of the Lower Paleozoic formations, Hazen Plateau and southern Grant Land Mountains, Ellesmere Island, Arctic Archipelago. Bull. geol. Surv. Can. 203, 134 pp.

Troelsen, J. C. 1956: The Cambrian of North Greenland and Ellesmere Island. In El sistema Càmbrico, su paleogeografía y el problema de su base. 20 Congr. geol. int. Mêxico Symp. 3(1), 71-90. 